\title{
KELUARGA DAN NEGARA: \\ RUANG NEGOSIASI DIRI DALAM NOVEL QUI A TUÉ MON PÈRE KARYA ÉDOUARD LOUIS
}

\author{
Yeni Artanti, Burhanudin \\ Universitas Negeri Yogyakarta \\ e-mail: yenarta@uny.ac.id
}

\begin{abstract}
(Title: Family and State: Space of Self-Negotiation in "Qui A Tué Mon Père" Novel's by Édouard Louis). Literary work reflects a culture outside its world. A family cannot be separated from society and country in which it is belonged to. Individuals in a family cannot be disconnected from their genetics. This qualitative descriptive study using Bourdieu's theoretical reference aims to describe the habitus, symbolic violence, and the arena of power in the novel "Qui a tué mon père" or "Who Killed My Father" by Édouard Louis. The results showed that the habitus manifested through the main character "Je" or "I" was obtained through an individual historical process as someone who was born in a poor and a working family that is structurally dominated by society and state. In conclusion, the main character who experienced symbolic violence not only from his family (father and mother) but also from his social environment (neighbor, school, and government) try to negotiate his identity through this novel.
\end{abstract}

Keywords: habitus, symbolic violence, arena of power, dialectical, structuralconstructivist

\section{PENDAHULUAN}

Karya sastra tidak lahir dalam kekosongan budaya (Teeuw, 2015, p. 56). Dalam kaca mata Plato, dunia dalam karya sastra merupakan dunia tiruan (Faruk, 2015). Dapat dikatakan bahwa dunia yang ada di dalam karya sastra merupakan hasil refleksi atau cerminan terhadap dunia sesungguhnya yang dihadirkan oleh pengarang dengan media bahasa.

Realitas sosial suatu masyarakat oleh sastrawan disampaikan salah satunya dengan novel. Jadi, langsung atau tidak langsung, kondisi sosial politik tertentu menjadi salah sumber inspirasi pengarang mendefinisikan 'diri'. Bagaimanapun juga, seperti disebut Rahayu (2020) bahwa pendefinisian diri oleh pengarang melalui karya sastra yang 'diramu' dengan bingkai sosial, budaya atau politik memerlukan pemikiran yang serius. Untuk memahaminya, juga perlu kajian mandalam.

Édouard Louis dalam wawacara dengan Théâtre National Strasbourg Youtube, 24 Juli 2018, menyebutkan bahwa menuliskan cerita tentang Ayah dan keluarganya, merupakan proses yang reflektif cukup panjang untuk berani mengungkap cerita pahit dan otentik tentang keluarganya (https://www.youtube. $\mathrm{com} /$ watch? $\mathrm{v}=\mathrm{GaJX} 4 \mathrm{pUw6Y})$. Melalui cerita berbentuk monolog Qui a Tué Mon Pere (2018) Édouard Louis, menyebutkankan bahwa apa yang menimpa tubuh dan jiwa ayahnya merupakan saksi bisu sejarah politik Prancis.

Novel seperti juga genre seni yang lain, sering menjadi media untuk menyampaikan kritik terhadap realitas sosial dan politik, salah satunya adalah novel karya Édouard Louis berjudul Qui a Tué Mon Père (2018). Karya ini merupakan novel realis yang bergenre autobiografi. Labonte (2019) menyebut Édouard Louis sebagai penulis yang mampu menceritakan riwayat hidup keluarganya dari satu pemerintahan ke pemerintahan lainnya. Melalui karya ini, penulis menceritakan masa kanak-kanaknya dengan jelas dan langsung tidak hanya terkait dengan kondisi fisik dan psikis ayah dan keluarganya namun juga sekaligus kondisi sosial, ekonomi, politik Prancis pada masa pemerintahan Jacques Chirac hingga Macron.

Novel ini menjadi salah satu karya terpopuler di Prancis sepanjang tahun 2019 dan 
telah diterjemahkan ke dalam berbagai bahasa, namun demikian belum ada terjemahannya dalam bahasa Indonesia. Novel ini telah didiskusi di beberapa media ternama seperti, London Review Book, Media Part, Europel dan Le Grand Librarie. Adaptasi ke dalam bentuk teater sukses dilakukan beberapa kali oleh beberapa kelompok teater. Salah satu adaptasi dipentaskan, disutradai, dan dilakonkan oleh aktor terkenal, yaitu Stanislas Nordey bersama Teater Vidy dalam International Teater Strassbourg, 24 sampai 27 Februari 2020 di ruang Charles Apothéloz (https://vidy.ch/quia-tue-mon-pere).

Berdasarkan penelusuran dokumen yang telah dilakukan, sampai saat ini, belum ditemukan publikasi artikel yang mengkaji Qui a Tué Mon Père karya Édouard Louis. Untuk itu, penelitian dengan menggunakan kajian sosiologi sastra khususnya strukturalkonstruktivisme (teori Bourdieu) ini dimaksudkan untuk memberikan gambaran tentang bagaimana habitus, kekerasan simbolik, dan arena kekuasaan direpresentasikan melaui novel tersebut.

Habitus merupakan titik sentral untuk memahami pendekatan Bourdieu. Masyarakat tidak hanya dibangun oleh struktur sosial tapi juga struktur mental individu dan kolektifnya yang muncul melalui pola perilaku dan kebiasaan tertentu. Sebagai contoh anakanak dari kelas pekerja cenderung mencari pekerjaan sebagai pekerja demikian juga anak dari kelas menengah cenderung dapat menikmati karya sastra berkelas (Willis, 1977 dalam Grenfell, 2008, p. 50). Bourdieu (1970, 1989) lebih lanjut menjelaskan bahwa tidak menutup kemungkinan bahwa seseorang dapat saja mengubah habitusnya melalui 'strategi' yang terjadi karena agen-agen di dalam suatu struktur sosial memiliki pengalaman yang unik sehingga berkontribusi untuk mengubah habitus seseorang.

Kekerasan simbolik menurut Bourdieu muncul melalui menggunakan bahasa (Grenfell, 2008 : 183). Walaupun kekerasan simbolik sifatnya kasat mata namun dampak yang ditimbulkan dapat saja membentuk habitus seseorang. Kekerasan simbolik melalui bahasa dapat dilihat sebagai media penindasan atau opresi satu kelas terhadap kelas lainnya (Bourdieu, 2011, p. 1). Kekerasan bentuk inilah yang kemudian selain menjadi media reproduksi habitus kelas, juga menjadi strategi dominasi. Bentuk-bentuk kekerasan yang lakukan melalui bahasa mengakibatkan penderitaan psikologis seperti perasaan termarjinal bagi individu atau kelompok yang menjadi korban.

Arena adalah tempat bagi pergulatanpergulatan dominasi terjadi (Bourdieu, 2010, p.22). Dinamika sosial sebagai sebuah pertarungan antara yang terdominasi dan yang mendominasi terjadi dalam arena dan di dalam arena terdapat dua konsep yaitu yaitu, strategi dan jejak atau trajectoire. Strategi yang dilakukan oleh agen yang terdominasi akan berbeda dengan agen yang mendominasi. Agen yang terdominasi akan melakukan sesuatu untuk meningkatkan statusnya atau melawan agen yang mendominasi. Sedangkan agen yang dominan juga akan melakukan strategi yang berbeda, dia akan mencoba mempertahankan statusnya atau menindas yang lain. Bourdieu melihat arena sebagai tempat terjadinya persaingan antar kaum dominan dan terdominasi, antara pertempuran dan perjuangan - baik itu di arena pendidikan, politik, ekonomi, bisnis, dan yang lainnya. Maka dari itu untuk menguasai sebuah arena agen harus memiliki habitus dan modal yang memadai. Modal bisa diartikan sebagai hasil akumulasi dari habitus meliputi modal kapital, budaya, sosial, dan simbolik yang merupakan akumulasi dari semua jenis modal sebelumnya (Bourdieu, 2011).

\section{METODE}

Penelitian ini merupakan penelitian deskriptif-kualitatif. Subjek penelitian ini adalah novel Qui a Tué Mon Père karya Édouard Louis yang diterbitkan oleh Les Éditions de Seuil pada tahun 2018. Objek penelitiannya adalah bagian-bagian dalam cerita berupa kata, kalimat, frasa, dan paragraf dalam novel yang berkaitan dengan habitus, kekerasan simbolik, dan arena kekuasaan. Data yang dihasilkan kemudian dianalisis menggunakan teori sosiologi sastra Pierre Bourdieu atau sering disebut sebagai kajian strukturalisme konstruktivistik. Pisau analisis 
ini juga menjadi acuan utama dalam melakukan inferensi. Kegiatan inferensi menurut Zuchdi (1993), digunakan untuk menganalisis makna, maksud dan akibat dari komunikasi. Langkah-langkah analisis adalah (1) membaca secara berulang data yang terkumpul, (2) menentukan dan mengelompokkan tema dominan dan memaknainya dengan menginterpretasikannya.

Validitas yang digunakan dalam penelitian ini adalah validitas argumentatif dan komulatif. Validitas argumentatif yaitu mendiskusikan data dengan teman sejawat dan tim peneliti. Sedangkan validitas komulatif digunakan dengan membandingkan temuan penelitian dengan hasil penelitian terdahulu, yaitu berupa referensi-referensi lain yang terkait yang digunakan sebagai pembanding dalam menginterpretasikan hasil penelitian agar diperoleh reliabilitas penelitian.

\section{HASIL DAN PEMBAHASAN \\ Hasil}

Berikut disampaikan hasil penelitian yang diklasifikasikan berdasarkan (1) habitus tokoh, (2) kekerasan simbolik, dan (3) arena kekuasaan yang dominan muncul dalam novel Qui a Tué Mon Père karya Édouard Louis.

Tabel 1. Habitus Tokoh Novel "Qui a Tué Mon Père” Karya Édouard Louis

\begin{tabular}{ccl}
\hline No. & \multicolumn{1}{c}{ Tokoh } & \multicolumn{1}{c}{ Habitus Tokoh } \\
\hline 1. & Kakek & Meninggalkan sekolah untuk bekerja di pabrik. \\
& & Alkoholik, kasar terhadap keluarga. \\
2. & Ayah & Alkoholik dan berlaku kasar. \\
& & Meninggalkan sekolah untuk bekerja di pabrik. \\
& & Menentang sifat-sifat feminin anak laki-lakinya, menolak perilaku 'je' atau \\
& & Louis. \\
3. Je / Aku & Menerima penolakan di keluarga. \\
& & Merasa tidak sempurna, tidak memenuhi harapan keluarga sebagai laki- \\
& & laki. \\
& & Feminin dan menjadi gay. \\
\hline
\end{tabular}

Tabel 2. Kekerasan Simbolik dalam Novel “Qui a Tué Mon Père” karya Édouard Louis

\begin{tabular}{|c|c|c|}
\hline No & Pelaku & Bentuk Kekerasan Simbolik \\
\hline 1. & Ayah & Perilaku kasar, penolakan, kebencian. \\
\hline 2. & Ibu & $\begin{array}{l}\text { Kritikan tajam dan pedas terhadap fisik tokoh 'Je' yang feminin. } \\
\text { Penolakan dan sikap kebencian. }\end{array}$ \\
\hline 3. & Teman/ Sekolah & $\begin{array}{l}\text { Ejekan atau bullying (verbal dan fisik). } \\
\text { Dianggap lemah. }\end{array}$ \\
\hline 4. & Pemerintah & $\begin{array}{l}\text { Kebijakan Pemerintah Prancis yang tidak adil terhadap kaum buruh dan } \\
\text { berpihak kepada pemilik modal. }\end{array}$ \\
\hline
\end{tabular}

Tabel 3. Arena Kekuasaan dalam Novel "Qui a Tué Mon Père” karya Édouard Louis

\begin{tabular}{lll}
\hline No & Arena Kuasa & \multicolumn{1}{c}{ Bentuk } \\
\hline 1. & Keluarga & $\begin{array}{l}\text { Kuasa patriarki menekan dan mendominasi tokoh "Je" atau aku. } \\
\text { Mulai dari Kakeknya, Ayahnya, serta Ibunya yang secara genetis lebih } \\
\text { berkuasa. }\end{array}$ \\
2. & Masyarakat/ & $\begin{array}{l}\text { Nilai-nilai kebenaran yang dianut masyarakat tempat tokoh utama/Louis } \\
\text { menyebabkan tokoh "Je" tersingkir. Tokoh utama ditolak oleh peer group } \\
\text { karena dianggap berbeda, lemah dan miskin. }\end{array}$ \\
& & $\begin{array}{l}\text { Kebijakan-kebijakan pemerintah yang tidak memihak kepada kelas pekerja } \\
\text { dan miskin menjadikan tokoh 'Je' dan keluarganya semakin terdominasi } \\
\text { dan menjadi kelompok kelas yang tersisih. }\end{array}$ \\
\hline
\end{tabular}




\section{Pembahasan}

\section{Habitus dalam novel Qui a Tué Mon Père karya Édouard Louis.}

Melalui Tabel 1, terlihat bahwa terdapat persamaan habitus antara tokoh Kakek dan Ayah dari tokoh "Je" atau 'Aku', yaitu memilih untuk meninggalkan sekolah dan menjadi buruh atau pekerja untuk mendapatkan uang dan mengendalikan modal, menjadi jantan dalam keluarga yang di mereka bentuk. Kejantanan bagi mereka adalah menguasai modal ekonomi dengan bekerja (tidak meneruskan sekolah) sehingga dapat mengatur dan mengelola keluarganya. Dapat dikatakan bahwa habitus tokoh Ayah mereproduksi habitus tokoh Kakek yang memiliki perilaku yang gemar minum dan juga berperilaku kasar terhadap keluarganya. Dapat disimpulkan bahwa perilaku dan nilai yang dianut oleh tokoh Ayah dalam novel ini adalah hasil transformasi nilai yang terdapat pada diri tokoh Kakek. Hal itu yang mengakibatkan tokoh Ayah dan Kakek dalam novel memiliki kondisi sosial dan ekonomi yang sama (Louis, 2018).

Bourdieu menyebutkan salah satu ciri-ciri habitus yaitu transposable, mampu berpindah dari satu agen ke agen yang lain. Gambaran habitus tokoh Kakek dan Ayah bahwa keduanya lebih mementingkan dominasi secara fisik melalui sikap mereka yang kasar, suka berkelahi dan bertengkar, bahkan di depan anak-anak mereka (Louis, 2018, p. 55). Kesamaan habitus antara Ayahnya dengan Kakeknya adalah praktik hasil reproduksi dari pengamatan. Kakeknya yang merupakan replika dari habitus Ayahnya Ayah dari Ayahnya (Kakek Buyut sang tokoh utama). Kondisi ini disebut sebagai habitus yang telah direproduksi (Louis, 2018, p. 34).

Demikian juga dengan pandangan tokoh Kakek dan Ayah tentang laki-laki sangat berbeda dengan tokoh 'Aku' yang feminin dan seperti perempuan. Ejekan dan juga penolakan terhadap kondisi fisik tokoh 'Aku' seperti terlihat dalam kutipan berikut:

....Depuis ma naissance je t'avais vu mépriser tous les signes de féminité chez un homme, je t'avais entendu dire qu'un homme ne devait jamais se comporter comme une femme, jamais. (Louis, 2018: 18).

...sejak aku (Je) lahir, aku tahu kamu (Ayah) menentang segala tanda-tanda feminim pada diriku. Kamu pernah bilang bahwa laki-laki tidak boleh bertingkah seperti perempuan, jangan pernah." (Louis, 2018: 18).

Ayahnya mewakili masyarakat dimana tempatnya berada selalu mengatakan dengan tegas bahwa anaknya (Louis) untuk tidak boleh bertingkah seperti perempuan, karena itu memalukan (Louis, 2018). Nilai yang dimiliki kelompok sosial semacam ini akan terinternalisasi dalam benak anak sebagai generasi penerus mereka. Jika anak tidak sesuai dengan harapan, seperti Louis, maka perasaan ditolak dan perasaan bersalah akan menjadi habitusnya yang baru yang akan membentuk identitas dirinya. Bourdieu (2011) menyebutkan bahwa habitus juga merupakan proses di mana seorang individu membentuk identitasnya.

Interaksi yang terjadi diatara para agen atau tokoh di dalam struktur keluarga secara genetis menurut Bourdieu menjadi faktor yang mampu melahirkan kesamaan kondisi dan praktik hidup (1980: 98). Namun, dapat juga justru berlawanan. Dalam kasus tokoh 'Aku' justru memiliki pandangan yang bertolak belakang. Habitus tentang ukuran dan pandangan kemachoan atau kejantanan Kakek, Ayah serta Kakak justru ditolak oleh Louis / Je yang memilih untuk menghasilkan habitus baru sebagai laki-laki yang feminin. Tokoh Louis memilih untuk berbeda dengan habitus keluarganya. Dia tidak keluar dari sekolah, tidak bekerja sebagai buruh, dan tidak langsung menikah, meninggalkan lingkungan keluarganya / desanya untuk kuliah di Jurusan Ilmu Sosiologi di École Normale Supérieur. Di Paris, Louis memasuki habitus baru dengan menerima dirinya dan menjadi bagian dari komunitas barunya yang menerimanya apa adanya. Hal ini merupakan bentuk perlawanan terhadap struktur sosial yang telah mapan di lingkungannya. Louis memilih 
untuk bergabung pada komunitas yang dapat menerimanya, komunitas yang terdominasi dan tersisihkan, komunitas kaum gay (Louis, 2018, p. 35). Sebagaimana diungkap oleh Marx dalam Barnier (2010: 13) bahwa kelas sosial baru dapat terbentuk sebagai akibat dari pertentangan ekonomi antar kelas, kesamaan budaya, atau ketertarikan secara kolektif.

Hidup dalam kekacauan situasi keluarga dan juga lingkungan yang keras, kungkungan dan keterikatan dengan alkohol, justru menjadikan tokoh 'Aku' menjadi seorang yang feminin. Kekerasan fisik yang dirasakan dan diterima oleh Ibu dan Nenek tokoh Aku memunculkan perasaan empati dan justru menjadikan tokoh Aku berperilaku lemah lembut (Louis, 2018, p. 24). Tokoh Aku menolak 'budaya' mabuk yang dapat mengubah perilaku seseorang dari lembut menjadi kasar tidak terkontrol. Kutipan berikut memberikan gambaran lingkungan kehidupan tokoh 'Aku'

...Je n'étais pas innocent. En 2001, mon grand-frère avait essayé de le tuer, lui, mon père. Mon grand-frère, donc, en plein milieu du dîner, a attrapé mon père par le cou devant le reste de la famille et il a commencé à lui claquer le dos contre le mur de la cuisine. Il le tueait, ce n'était pas la première fois qu'ils se battaient tous les deux. Mon père hurlait, il le suppliait je n'avais jamais vu mon père supplier quelqu'un, et mon gran-frère criait, je vais te buter fils de pute.. (Louis, 2018: 55).

...Aku tidak bersalah. Saya masih ingat. Tahun 2001, kakakku mencoba membunuhnya, ayahku, kakakku ketika sedang makan malam, dia mencekik leher ayahku di depan semua orang. Lalu dia membenturkannya ke tembok dapur. Dia memukulnya sejadi jadinya, ini bukan pertama kali mereka bertengkar. Ayahku berteriak, dia memohon saya tidak pernah melihat ayahku dicemooh seperti itu, lalu kakakku berteriak, aku akan membunuhmu dasar brengsek... (Louis, 2018, p. 55).
Kesamaan habitus dari keluarga Louis seolah-olah turun-temurun, taken for granted, dari tokoh Kakek ke Ayah kemudian ke Kakak yang kemudian dianggap sebagai suatu kebenaran. Habitus semacam ini tidak hanya terjadi pada keluarga tokoh $\mathrm{Aku}$, tetapi dimiliki juga lingkungan tetangga tempat mereka hidup. Untuk dapat keluar dari habitus tersebut, seseorang perlu berjuang untuk mendobrak dominasi nilai keluarga dan masyarakat terhadap dirinya.

Bourdieu (1980) menyebutkan bahwa habitus merupakan hasil perjalanan sejarah seseorang dan dapat menghasilkan praktik baru baik secara individu maupun kolektif. Kebiasaan yang secara bawah sadar yang (tanpa sengaja / dengan sengaja) diperlihatkan kepada anak oleh orang tua dapat menjadi pengalaman yang diserap oleh anak.

Tokoh Kakek yang keluar sekolah, peminun, keras diterima Ayah menjadi habitus yang sama. Kebiasaan mengonsumsi alkohol bukan hanya terjadi pada keluarga Louis tetapi mewakili habitus kelas sosial pekerja di Prancis. Orang-orang yang berada pada kelas sosial yang sama cenderung memiliki habitus yang sama, sebagai contoh agar dianggap dewasa, anak muda di lingkungan Louis harus kuat minum dan mabok (Louis, 2018, p. 22). Padahal kebiasaan tersebut justru merugikan diri sendiri dan keluarga mereka. Kesamaan rasa yang dimiliki komunitas di mana seseorang dilahirkan dan tumbuh, melahirkan kesadaran terhadap kelas dan kelompok yang sama. Dalam kelas pekerja, solidaritas yang kuat dimiliki dan dianut sebagai nilai bersama (Couronnet, 2010-2011: 35).

Sama halnya habitus dalam keluarga, habitus pada masyarakat baik lingkungan tetangga (teman) ataupun sekolah mempengaruhi habitus seseorang. Bourdieu (1970) menyebutkan bahwa bahwa sekolah merupakan lembaga pendidikan tempat dimana hierarki sosial dipertahankan dan direproduksi. Anak-anak yang kuat cenderung akan mendominasi anak-anak yang lemah. Anakanak yang lemah rentan terhadap persekusi atau bullying dan memberikan peluang kegagalan sekolah yang lebih tinggi. 
Kondisi sosial yang kurang menguntungkan, sadar atau tidak sadar, mempengaruhi kondisi psikis anak-anak kelas pekerja. Seringkali, mereka tumbuh dengan self esteem atau kepercayaan diri yang rendah karena sering mendapat tekanan dari kelompoknya. Selain itu, anak-anak dari kelas pekerja juga sering kali mengalami kesulitan untuk melanjutkan pendidikan ke jenjang yang lebih tinggi. Journal Officiel de la Republique Française (2015, p. 67) melaporkan bahwa anak-anak yang terlahir dalam keluarga miskin di Prancis lebih sering gagal dalam dunia Pendidikan. Sekolah merupakan lembaga pembentuk habitus dan reproduksi kelas (kelas yang mendominasi atau yang terdominasi).

Tokoh Aku atau Louis, mencoba menegosiasikan diri dan posisinya di dalam keluarga yang secara genetis tidak terpisah darinya. Keluarga yang dimiliki dan memilikinya, meskipun membencinya. Tokoh Aku ingin berbeda dengan tokoh Ayah dan Kakek. Aku tidak ingin bekerja di pabrik seperti Ayahnya dan tidak mau mengulang kesalahan Kakek dan Ayahnya. Tindakan ini memunculkan konflik, yaitu konflik dengan ayahnya, lingkungannya dan terutama dengan dirinya (Louis, 2018 : 67-68).

Keputusannya untuk meninggalkan desanya dan memilih kuliah di École Normale Supérieure (Paris) untuk belajar Ilmu Sosiologi merupakan salah satu cara untuknya menyelesaikan konflik dan berusaha untuk berdamai dengan dirinya dan keluarganya.

Dapat dikatakan bahwa kepergiannya dari desa tempatnya dibesarkan adalah usahanya untuk mencari tahu tentang jati dirinya yang ternyata tidak dapat terlepas dari keluarga dan masyarakatnya. Untuk itu, Louis menuliskan cerita ini. Cerita tentang dirinya, keluarganya dan negaranya. Dalam perjalanannya mencari jati dirinya, dia akhirnya kembali ke rumah dan memilih untuk berdamai dengan ayahnya, keluarganya.

Kritikan-kritikan terhadap pemerintah Prancis merupakan caranya memahami siapa dirinya, keluarganya, negaranya. Dengan berbekal berbagai macam bacaan di bangku kuliah, Louis ingin memperbaiki hubungan dirinya dengan ayah dan keluarganya, dengan masyarakatnya dan dengan negaranya. Louis menghapus rasa malunya karena memiliki seorang Ayah yang tidak mencintainya, dari kelas pekerja, memiliki kehidupan yang pahit karena miskin (London Book Review, 2019).

Buku ini merupakan habitus baru yang diciptakan penulisnya untuk melawan keterkungkungan dirinya. Pembebasan diri penulis dilakukan melalui rangkaian katakata bernada menanyakan dan mengkritik pemerintah dengan kecerdasan.

\section{Kekerasan Simbolik dalam Novel Qui a Tué Mon Père karya Édouard Louis.}

Tabel 2. menunjukkan bahwa kekerasan simbolik yang paling sering muncul dan dialami oleh tokoh Aku atau Louis adalah melalui bahasa yang kemudian termanifestasi melalui sikap, tutur kata dan juga perbuatan tokoh-tokoh lain (terutama Ayah dan Ibunya) terhadap keberadaannya.

Penolakan Kakek, Ayah, Ibu, dan juga anggota keluarga lainnya termasuk lingkungan sekolah atau masyarakatnya terhadap kondisi fisik tokoh Louis yang seperti perempuan mampu memunculkan persepsi diri yang ditolak, tidak dicintai, dibenci, dihina sehingga tokoh Aku memilih menyingkir dan berbeda dengan habitus keluarganya. Tokoh Aku memilih pindah ke Paris dan bersekolah di École Normale Supérieur untuk menuntut Ilmu Sosiologi, dan menjadi mahasiswa dengan uang saku minim, tokoh Aku / Louis mencoba membangun habitusnya sendiri, yang berbeda dengan keluarga dan mengikuti ritme kehidupan dan kelompok baru yang memiliki pengalaman yang kurang lebih sama dan dapat saling menerima dirinya.

Kekerasan simbolik sering kali tidak terlihat namun dampaknya luar biasa terhadap perkembangan pribadi seseorang. Kekerasan simbolik dari keluarga akan dibawa seumur hidup dan untuk menghapusnya dari ingatan memerlukan waktu yang lama, bahkan dapat menjadi trauma. Kekerasan simbolik berbeda dengan kekerasan secara fisik yang dapat sembuh dalam hitungan hari. Seperti terlihat dalam kutipan berikut ketika tokoh Aku 
mencoba bertanya dan meminta jawaban dari Ayahnya.

...pourquoi tu te comportes toujours comme une fille? Dans le village tout le monde dit que t'es pédé, nous on se tape la honte à cause de ça, tout le monde se moque de toi. Je ne comprends pas pourquoi tu fais ça. Je ne réponds pas. Je sors de la maison, je ferme la porte sans rien dire et je ne sais pas pourquoi je ne pleure pas... (Louis, 2018, p. 59).

... mengapa sikapmu selalu seperti perempuan ? Di desa kita semua orang menganggapmu seorang gay, kami malu dengan itu semua, semua orang mengejek kami gara-gara kamu. Aku tidak paham mengapa kamu seperti itu. Tidak paham. Aku (Louis) keluar dari rumah, pergi menutup pintu tanpa berkata apapun dan aku tak tahu mengapa aku tidak menangis... (Louis, 2018, p. 59).

Kekerasan simbolik tidak hanya berasal dari Ayah tokoh Louis, tapi juga dari ibunya yang menolak untuk memberikan hadiah ulang tahun yang diminta karena dianggap sebagai hadiah yang hanya pantas diterima oleh perempuan (Louis, 2018, p. 38). Pernyataan tokoh Ayah dan Ibu tentang nilai-nilai yang seharusnya dianut oleh semua anggota, tidak terpenuhi oleh tokoh Aku.

Tokoh Aku dalam konteks ini memberi atau merubah habitus yang berasal dari nilainilai atau pendidikan yang dianut keluarga, ia mendapatkan doxa tentang nilai-nilai yang harus dijunjung oleh seorang laki-laki namun tidak sanggup dijalaninya. Tokoh utama dapat memahami peran laki-laki dan perempuan yang secara alamiah diterima oleh Kakek / Ayah dan Ibunya, tetapi tokoh Aku memilih jalan yang berbeda dari pandangan Ayah dan Ibunya serta masyarakat tempatnya tinggal.

Kekecewaan demi kekecewaan karena tidak dianggap ada, menjadikan tokoh Aku menjadi seorang yang selalu mempertanyakan dirinya sendiri tentang kedirian dan juga identitasnya sebagai anggota keluarganya. Melalui keluarganya, tokoh Aku selalu bertanya dan mencari posisinya, mendialogkan kediriannya. Dia ingin memahami bagaimana keluarganya melihatnya. Tokoh Aku atau Louis selalu mempertanyakan dirinya sendiri tentang keberadaannya di mata Ayahnya, Ibunya dan Keluarganya.

...le soir ... est-ce que je t'ai blessé parce que j'avais fait la fille et parce que tu pensais que tes amis te jugeraient pour ça qu'ils rendaient coupable de m'avoir élevé comme une fille? (Louis, 2018, p. 40).

..suatu sore ... apakah aku (Louis) menyakitimu karena aku seperti perempuan dan apakah kamu merasa bersalah kepada teman-temanmu yang menganggapmu salah mendidikku sebagai perempuan ?... (Louis, 2018, p. 40).

Penolakan ayah tokoh Aku demikian nyata, seperti terlihat dalam kutipan berikut:

...un soir, dans le café du village, tu as dit devant tout le monde que tu aurais préféré avoir un autre fils que moi. Pendant pluesieurs semaines j'ai eu envie de mourir..(Louis, 2018: 70)

... suatu sore, di suatu kafe di desa, kamu (ayah) mengatakan kepada semua orang bahwa berharap memiliki anak laki-laki selain saya. Selama beberapa minggu mendengar itu ingin rasanya aku mati... (Louis, 2018: 70).

Pernyataan ini terus diulangi oleh tokoh Ayah kepada anaknya. Sehingga tokoh utama memiliki cara pandang baru terhadap dirinya, yaitu sebagai anak laki-laki yang tidak laki-laki. Konsep yang tertanam dalam diri tokoh ini kemudian tidak hanya berbentuk nilai yang ada dalam pikiran tetapi menjadi perilaku yang teraktualisasai, menurut Bourdieu (2011) disebut sebagai hexis. Selain perlakuan dari Ayahnya, perlakuan teman-teman sekolah yang berulangkali diterimanya, memengaruhi pikiran si tokoh utama. 
Tokoh aku menjadi objek dominasi tokoh-tokoh yang secara genetis akan selalu melekat dalam diri Aku. Secara struktur dan genetis, tokoh Aku berada dalam posisi yang lemah dan tidak dapat melawan. Baginya keluarga adalah tempat dimana kepedihan dan kesedihan selalu didapatkan. Alih-alih memberinya perlindungan, keluarga justru 'mengancam' kedirian tokoh Aku. Bahkan ketika tokoh Aku mendapat perundungan di antara teman-temannya, Ayah tidak dapat hadir untuk menenangkannya. Ayah adalah sosok yang sering kali 'hilang' secara fisik (karena harus bekerja) ataupun psikis untuk tokoh Aku (karena penolakannya). Padahal bagi seorang anak laki-laki, tokoh ayah adalah tokoh sentral yang sangat diperlukan. Tokoh aku adalah salah satu siswa korban bullying dari teman di sekolah atupun masyarakat. Berdasarkan laporan Unicef Prancis (2012) dari penelitian yang dilakukan oleh Debarbieux menunjukkan bahwa satu dari sepuluh anak di Prancis pernah mengalami berbagai macam penghinaan atau bullying. Pengalaman perundungan yang terjadi di sekolah seringkali membuat siswa menjadi tertutup, mengisolasi diri bahkan sampai meninggalkan sekolah.

Dapat dikatakan bahwa keluarga sebagaimana disebutkan oleh Bourdieu (2011) juga melanggengkan struktur dominasi, yaitu orang tua kepada anaknya. Dominasi orang tua terjadi karena orang tua adalah pemilik modal ekonomi, budaya dan sosial bagi seorang anak.

Selain terjadi di dalam keluarga (orang tua terhadap anak), kekerasan simbolik juga terjadi antara pemerintah kepada masyarakat atau keluarga. Dalam novel Qui a Tué Mon Père karya Édouard Louis (2018) kekerasan simbolik termanifestasi berupa ungkapan pemerintah yang diwakili oleh presiden yang mendeskreditkan kelas pekerja dan membuat kebijakan-kebijakanyangtidakmenguntungkan bagi kaum pekerja yang terwakili oleh tokohtokoh seperti keluarga tokoh Ayah (Louis, 2018). Sebagai kelas pekerja, keluarga Ayah Louis merupakan salah satu potret carut marutnya kehidupan masyarakat Prancis yang terdominasi oleh kekuasaan dan kesulitan untuk melakukan perlawanan terhadap dominasi (ekonomi, sosial, ataupun budaya). Kritikan Louis terhadap pemerintah Prancis dimaknai sebagai salah satu suatu bentuk keprihatinan terhadap permasalahan-permasalahan yang dihadapi masyarakat Prancis.

\section{Arena Kekuasaan dalam Novel Qui a Tué Mon Père Karya Éduard Louis.}

Terlihat melalui Tabel 3, bahwa arena kekuasaan dalam novel ini terjadi antara keluarga, masyarakat dan pemerintahan. Kebijakan-kebijakan pemerintah Prancis dianggap oleh tokoh Aku sebagai pemerintahan yang gagal melindungi orang miskin, kaum pekerja (Louis, 2018).

Tokoh Aku mencoba menjadikan arena keluarga sebagai sarana untuk mendefinisikan dan mencoba berdamai dengan dirinya sendiri. Dia ingin menjadi dirinya sendiri dengan tidak meniru Kakek dan Ayahnya. Tokoh Aku ingin membangun dunianya sendiri dengan bersekolah dan tidak langsung bekerja, meskipun hal tersebut memerlukan perjuangan, "...Tu ne voulais pas reproduire la vie de ton père et de ton grand-père avant toi. Ils avaient travaillé directement après l'enfance, à quatorze ou quinze ans. ... (Louis, 2018. p. 41). - ... kamu tidak ingin menjalani hidup seperti ayahmu ataupun kakekmu. Mereka langsung bekerja ketika masih kecil, umur 14 tahun... (Louis, 2018, p. 41).

Tokoh Aku melalui karya ini mencoba terus memahami keberadaannya, dalam kebencian dan trauma terhadap segala macam ejekan baik di rumah, lingkungan tetangga atau sekolah yang menjadikannya sebagai ruang untuk berkontemplasi. Tokoh Aku mencoba medefinisikan dirinya melalui ruang atau arena keluarganyaberikutpenggambarannya. Melalui tokoh-tokoh lain, Aku mencoba memahami siapa sejatinya dirinya. Berikut kutipannya :

...Tu es ne dans une famille de sept ou six enfants. Ton père travaillait dans une usine, ta mère ne travaillait pas. Ils n'avais jamais connu autre chose que la pauvreté. Je n'ai Presque rien d'autre à dire sur ton enfance... (Louis, 2018: 21). 
...Kamu lahir dalam sebuah keluarga yang terdiri dari enam atau tujuh anak. Ayahmu bekerja di pabrik, ibumu tidak bekerja. Mereka tidak tahu apapun kecualikemiskinan, sayatidakmemiliki hal lain untuk menggambarkan masa kecilmu. (Louis, 2018, p. 21).

Arena keluarga yang didominasi sikap patriarkis di lingkungan tempat Aku lahir dan tumbuh merupakan arena untuknya untuk menggembleng dirinya sebagai lakilaki yang justru berbeda dengan Ayah, Kakek, serta Kakaknya yang dominan keras, kasar dan menonjolkan sifat kejantanannya secara fisik. Ayah dan Kakeknya yang kehilangan masa mudanya karena harus banting tulang menghidupi anak-anak dan keluarga yang dibangunnya merupakan gambaran masyarakat pekerja pada umumnya. Tokoh utama menjelaskan kondisi Ayahnya sebagai bagian dari masyarakat yang dipersekusi oleh kebijakan politik. Ketidakadilan pemerintah dalam membuat berbagai jenis kebijakan menjadi permasalahan yang tak selesai dikalangan kelas pekerja. Tercatat pada tahun 2002, satu dari empat orang pekerja buruh antara umur 15-64 tahun yang masih atau sudah berhenti bekerja mengalami penyakit kronis bahkan cacat, terdapat 1,1 juta orang yang terkena penyakit akibat pekerjaan (CREDOC, 2012: 1).

Kurang berpihaknya berbagai kebijakan tersebut membuat kaum terdominasi kehilangan hak untuk ikut berpartisipasi dalam bidang lain. Tokoh utama bahkan sampai berkesimpulan bahwa kebijakan politik dengan berbagaiketimpangansosialyangdiciptakannya telah membunuh Ayahnya. Modal politik, ekonomi dan modal budaya yang dimiliki oleh pemerintah, terutama Presiden Prancis tidak digunakan untuk memihak kaum miskin, yaitu kelas pekerja yang semakin terjepit dan terdominasi, hidup dalam kemiskinan.

Berbagai kebijakan pemerintah Jacques Chirac yang tidak lagi memberikan keringanan bagi pembayaran obat-obatan untuk kaum miskin merupakan tindakan yang semena-mena : ...le gouvernement de Jacques Chirac, résident de la France pendant douze ans, et son ministre de la santé Xavier Bertrand, ont annoncé que des dizaines de médicaments ne seraient plus remboursés par l'État, dont en grand partie les médicaments contre les troubles digestif... Jacques Chirac et Xavier Bertrand te détruisent les intestines... (Louis, 2018: 75)

... pemerintah Jacques Chirac, yang memimpin selama 12 tahun, dan menteri kesehatannya Xavier Bertrand, mengumumkan bahwa puluhan obatobatan (berkaitan penyakit lambung) tidak lagi dapat di-reimburse oleh pemerintah, .... dengan kata lain Jacques Chirac dan Xavier Bertrand merusak ususmu (Louis, 2018, p. 75).

Berdasarkan laporan Le Monde (2006) Menteri Kesehatan Bernard Xavier mengumumkan bahwa mulai tanggal 1 Maret 2006 terdapat 152 jenis obat-obatan yang tidak lagi ditanggung oleh pemerintah. Tentu hal ini semakin memperburuk kondisi tokoh Ayah Louis, yang harus tetap bekerja meski dalam kondisi sakit-sakitan dan harus tetap membayar berbagai jenis obat-obatan untuk penyakit yang dideritanya, karena pemerintah.

Ketimpangan danjugarepresikebijakan terjadi antara pemerintah kepada masyarakat, terutama bagi kaum miskin terpaksa harus berhenti bekerja karena sakit parah akibat. Sayangnya, pemerintah justru memberi label yang menyakitkan bagi golongan yang tak lagi mampu bekerja, 'sebagai masyarakat yang pemalas dan menjadi beban masyarakat.' (Louis, 2018, p. 75).

Selain itu, pernyataan-pernyataan yang disampaikan oleh Presiden Sarkozy dalam kampanye tanggal 23 April 2006, justru semakin menyudutkan kaum pekerja seperti Ayah tokoh Aku atau Louis. Padahal berdasarkan UU Prancis tanggal 2 Januari 2002 menyebutkan bahwa Negara atas nama Hak Asasi Manusia memberikan bantuan yang cukup kepada kelompok masyarakat tanpa melihat status sosial umur, mental yang 
menyebabkan mereka tidak mampu bekerja (Mediapart, 2012).

Demikian juga pada pemerintahan Nicholas Sarkozy dan pembantunya Martin Hirse yang alih-alih memberikan bantuan cukup kepada para pekerja yang sudah tidak mampu bekerja seperti tokoh Ayah Louis, justru menerapkan aturan yang tidak masuk akal bahwa untuk mendapat bantuan, mereka tetap diwajibkan untuk bekerja meskipun hanya menyapu jalan (meskipun dalam kondisi sakit) - (Louis, 2018, p. 76).

Pergantian Presiden Prancis dari Sarkozy ke Macron pada tahun 2017 menambah permasalahan baru terkait kondisi pekerja. Hal terebut karena Emmanuel Macron lebih suka menyebut para pekerja yang berhenti bekerja sebagai orang malas yang menghambat kemajuan negara (Louis, 2018, p. 79). Selain itu, aturan baru tentang PHK yang memberikan kelonggaran kepada perusahaan untuk memecat karyawan-karyawannya, semakin memberikan bukti bahwa para pekerja berada di posisi yang rentan, tidak diuntungkan dan terdominasi. Para pekerja tidak memiliki kekuatan dan kekuasaan untuk mengubah kebijakan pemerintah dan juga pemilik modal. Demikian juga ketika pemerintah memotong lima euro setiap bulannya untuk bantuan sosial, disisi lain pemerintah justru memberikan pengurangan pajak terhadap orang-orang kaya di Prancis (Louis, 2018, p. 83). Suatu kondisi yang ironis.

Pernyataan Presiden Macron menyakiti hati para pekerja yang tidak mampu bekerja karena sakit seperti halnya Ayah Louis, yang berhenti bekerja bukan karena malas bekerja tetapi karena sakit (Louis, 2018, p. 76). Data dari CREDOC (2012:2) menyebutkan bahwa $5.8 \%$ dari seluruh pekerja mengalami sakit pinggang dan leher dan lebih dari 3 dari sepuluh pekerja mengalami penyakit permanen atau cacat.

Berdasarkan laporan Fouquet (2004: 1-2) tercatat ada 1,1 juta orang terpaksa berhenti bekerja karena penyakit; 40\% diantaranya mengalami sakit di bagian punggung. Sistem negara industri yang bersifat memaksa dan menekan para pekerja memberikan dampak yang signifikan terhadap angka kemiskinan. Berdasarkan data International Labour Office (2015) angka kemiskinan di Prancis mencapai $14 \%$ dari total populasi, yang terdiri dari $50 \%$ kelas pekerja, tanpa pekerjaan dan pekerja miskin (ibid., p. 3). Dalam novel digambarkan oleh Louis sebagai berikut :

...tu étais fasciné par toutes les innovations technologiques, comme si à travers la nouveauté qu"elles incarnaient tu avais voulu insuffler dans ta vie un renouveau auquel tu n"avais pas eu droit. Tu commentais avec un mélange d"envie et d"admiration dans ta voix les pubs pour les nouveaux téléphones, les tablettes ou les ordinateurs. Tu ne les achetais pas, il coûtaient trop cher" (Louis, 2018:, p. 45).

...kamu terpesona dengan semua jenis inovasi teknologi, seolah-olah ketika melihat semua pembaruan itu, kamu ingin memberikan pembaruan pada hidupmu padahal kamu sudah tidak bisa. Kamu berkomentar dicampur dengan keinginan dan kekaguman ketika menonton iklan tentang ponsel baru, tablet dan laptop.. (Louis, 2018, p. 45).

... Pada tahun 2016, di bawah pemerintahan François Hollande dengan Myrian el Khomri sebegai Menteri Pekerjaan, menggantikan Manuel valls, mengadopsi 'undangundang pekerjaan yang memberikan lisensi dan ijin kepada perusahaan untuk memberikan tambahan kerja bagi pekerja...(Louis, 2018, p. 76).

Realitas kontemporer kebijakan pemerintah di Prancis pada tahun 2018 sejalan dengan penggambaran dalam novel Qui a tué Mon Père karya Eduard Louis (2018). Ketimpangan sosial yang semakin tinggi memunculkan kembali gerakan aksi masa Gillets Jaune (Berjas Kuning) yang terjadi di Prancis sejak November 2018. Aksi 
tersebut merupakan bentuk protes masyarakat Prancis akan kebijakan politik dan ekonomi pemerintah yang tidak berpihak pada rakyat kecil. Kebijakan politik Emanuel Macron yang tidak adil dengan menambah pembayaran pajak bagi orang miskin atas nama ekologi tetapi menutup SNCF (Perusahaan Kereta Api), kelas di sekolah, pelayanan publik, dan kantor pos. Kebijakan politik ini mewajibkan pajak untuk solar tapi tidak untuk minyak tanah (syndicollectif.fr). Gerakan ini merupakan perjuangan panjang kelas buruh sejak 1968 dengan menggelar aksi mogok kerja yang menjadi salah satu sebab terjadinya krisis ekonomi di Prancis (Solidaires Industrie, 2011: 33-34).

Karya Édouard Louis ini seperti catatan sejarah kaum pekerja yang tertindas oleh kebijakan politik pemerintah Prancis. Seperti pernyataan Édouard Louis "L'histoire de ton corps accuse l'histoire politique" (Louis, 2018). Ia mengatakan bahwa seolah-olah apa yang menimpa tubuh Ayahnya sebagai saksi bisu sejarah politik Prancis. Kondisi Ayahnya yang harus kehilangan masa mudanya hanya untuk terus bekerja di pabrik, meskipun sudah renta tetap masih terpaksa harus bekerja sambil sakit-sakitan. Seperti pernyataan Louis ketika Ayahnya menderita sakit parah kemudian pemerintah mengeluarkan aturan kerja yang memaksa Ayah-nya untuk tetap bekerja walaupun dengan kondisi demikian (Louis, 2018: 76).

Pada pemahaman inilah baginya (tokoh utama) politik adalah antara hidup dan mati, "Tu avais conscient que pour toi la politique était une question de vie ou de mort" (Louis, 2018). Posisi terdominasi adalah kondisi akan ketergantungan pada kebijakan politik, karena ia tidak mimiliki modal untuk mengakses politik, maka novel ini dapat dimaknai sebagai upaya penulis untuk terlibat secara aktif memperbaiki sistem-sitem dan kebijakankebijakan publik yang dianggap belum benar. Kritikan merupakan bentuk keterlibatan penulis, Louis, terhadap permasalahan bangsanya, Prancis. Ketidaktenangannya melihat ketakadilan di sekelilingnya dirangkai menjadi suatu cerita yang menarik. Dalam ranah kesusastraan Prancis, karya seperti ini termasuk karya literature engagée atau karya sastra yang melibatkan.

\section{SIMPULAN}

Setelahmembahas novel Quia TuéMon Père (2018) dapat disimpulkan bahwa novel ini merupakan arena produksi perjuangan tokoh Aku atau Louis untuk melakukan perlawanan terhadap kondisi dan keadaan yang tidak menguntungkan baginya dan bagi keluarganya. Arena baru sebagai ruang menegosiasikan dirinya sebagai penulis muda (umur 25) Prancis yang ternyata mendapat sambutan yang hangat dari para pembacanya.

Arena keluarga, masyarakat dan pemerintahan dengan Prancis dijadikannya sebagai ruang untuk menegosiasikan posisinya sebagai pribadi yang otentik serta sebagai individu anggota keluarga dan juga masyarakat yang juga layak untuk diterima dan dihargai melampaui dominasi-dominasi yang telah ada terlebih dahulu, yaitu dominasi terhadap nilainilai budaya, materi dan juga kekuasaan. Tokoh Aku mampu mengolah berbagai macam perasaan dan juga kepedihan selama menjadi seorang anak dari keluarga miskin dan berjuang melakukan perlawanan melalui pendidikan untuk memahami masyarakatnya sendiri melalui karya ini.

Kritikan tajam terhadap kebijakan pemerintah Prancis yang memperlebar jurang perbedaan antara kelompok-kelompok pekerja perlu mendapat perhatian para pemangku kebijakan. Secara umum, novel ini merupakan salah satu bentuk perlawanan penulis terhadap strukturisasi yang terjadi di dalam masyarakat Prancis. Selain itu, tidak berlebihan jika disimpulkan bahwa novel ini juga merupakan politis identitas dari pengarangnya untuk mendefinisikan dirinya, menegosiasikan dan memposisikan dirinya dalam dan melalui keluarga dan negaranya.

\section{UCAPAN TERIMA KASIH}

Peneliti mengucapkan terima kasih kepada seluruh panitia dan nara sumber yang telahmemberikesempatankepadapenelitiuntuk belajar dan berlatih dalam Pelatihan Penulisan 
Artikel secara intensif pada acara Konferensi Internasional Sastra Fakultas Bahasa dan Seni Universitas Negeri Yogyakarta/ICOLITE V, 22-23 September 2020.

Secara khusus peneliti mengucapkan terima kasih kepada Prof. Dr. Anwar Efendi, M.Si. yang telah memberikan masukan dan pendampingan dalam penulisan artikel ini. Selain itu, kami juga mengucapkan terima kasih kepada Dra. Alice Armini, M. Hum, yang telah memberikan masukan terhadap perbaikan kajian ini.

Semoga bermanfaat.

\section{DAFTAR PUSTAKA}

Bernier, L. M. (2010). La Classe Ouvrière Comme Sujet d'un Rapport Social. http:/lmbarnier.free.fr.

Bourdieu, P \& Passeron, J. (1970). La Reproduction : Elements Pour une Théorie du Systéme d'Ensignement. Paris: Minuit.

Bourdieu, P. (1980). Le Sens Pratique. Paris: Minuit.

Bourdieu, P. (1989). La noblesse d'état: grands école et ésprit du corps. Paris: Minuit.

Bourdieu, P. (2011). Choses Dites. (Uraian \& Pemikiran. Terj. Ninik Rochani Sjams). Yogyakarta: Kreasi Wacana. Original work published 1987.

Bourdieu, P. (2010). Arena Produksi Kultural: Sebuah Kajian Sosiologi Budaya. (Terj. Yudi Santosa). Yogyakarta: Kreasi Wacana. Original work published 1993.

Centre de Recherche Pour L'étude et l'observation des Conditions de Vie. (2012). Consommation et Mode de Vie. Credoc, hlm. 250.

Faruk. (2015). Pengantar Sosiologi Sastra. Yogyakarta: Pustaka Pelajar.

Grande Librarie (May 18, 2018). Édouard Louis Réhabilite Son Père. https://www. youtube.com/watch? $=$ =A7fZJMcUvI0

Grenfell, M. (2008). Pierre Bourdieu: Key Concepts. Stocksfield: Acumen.

Hudson, K., Louis, É. (2019). Édouard Louis. Who Killed My Father. London Book
Review. https://www.youtube.com/ watch? $\mathrm{v}=6 \mathrm{JeNRF} 7 \mathrm{EwGI}$.

Labonte, M. (2019). Qui A Tué Mon Père, Une Lasagna Littéraire. Retrieved 25/06/20. https://Karoo.me/livres/ quia-tue-mon-pere-lasagne-litteraire.

Journal Officiel de la Republique Française. (2015). Rapport Annuel sur l'État de la France en 2015. Paris.

Jenkins, R. (2004). Membaca Pemikiran Pierre Bourdieu. Yogyakarta. Wacana.

Louis, É. (2018). Qui a Tué Mon Père. Paris. Seuil.

Rahayu, L. M. (2020). Identitas Keindonesiaan dalam Drama Nyanyi Sunyi Revolusi Karya Amir Hamzah. Diksi, Vol 28, No 2, 114-124. https://doi.org/10.21831/ diksi.v28i2.

Labonte, M. (2019). Qui A Tué Mon Père, Une Lasagna Littéraire.

Le Monde. (2006). 152 médicaments ne seront plus remboursés par la 'sécu' a partir de mercredi. https://www. lemonde. fr/societe/article/2006/02/28/152medicamentsne-seront-plus-rem bourses-par-lasecu_745898_3224. $\mathrm{html}$ (Diakses pada tanggal 1 Juli 2020).

Minima sociaux et prestations socials. (2019). Le Revenue De Soladrité Active (RSA) Dress.

Ritzer, G. (2014). Sociological theory. (Saut Pasaribu, Rh. Widada, Eka Adi Nugraha, Trans). Yogyakarta : Pustaka Pelajar. (Original work published 2012).

Solidaires Industrie (2011). Le movement ouvrier et le syndicalisme (resume historique de 11789 a nos jours). Paris.

Syndicollectif.fr (2018). https://syndi collectif.fr/apres-le-26-mai-2018communique-du-collectif-rganisateur/.

Teeuw, A. (2015). Sastra dan Ilmu Sastra. Jakarta: Pustaka Jaya.

Théâtre Lausane. (2020). Stanislas Nordey/ Edouard Louis, Qui a tué mon père d'édouard louis. https://vidy.ch/quiatue-mon-pere. 
Théâtre National Strasbourg. (2018). Qui a tué mon pèred'édouard louis. https://www. youtube.com/watch? $\mathrm{v}=\mathrm{GaJX} 4 \mathrm{pUw} 6 \mathrm{Y}$.

Unicef France. (2012). En France: Le Harcelement Scolaire. Fiche. Thématique.
Zuchdi, D. (1993). Panduan Penelitian Analisis Konten. Yogyakarta: Lembaga Penelitian IKIP N Yogyakarta. 